\title{
The Influence of Institution on Entrepreneurship--- Based on the Development of Entrepreneurship in Shenzhen
}

\author{
Qiuning Yang \\ School of Marxism, Xuzhou Medical University, Xuzhou 221004,Jiangsu, P.R. China \\ email: giuning589@163.com
}

Key words: Institutional environment, Social culture, Institutional subversion.

\begin{abstract}
Because the business aspect of entrepreneurship is still kept apart from the institutional aspect in the research of Chinese entrepreneurship, this study aims to enrich the entrepreneurship literature by examining a specific aspect of the institutional environment which includes the political, the economical and the social-cultural environment. Since the economic reform in the 1970s, the entrepreneurial activities in Shenzhen have shown how the entrepreneurial models have evolved in different institutional environments. A triangle framework is to be specifically used for this study to reveal the dynamic power for the initiative activities and its inner logic in entrepreneurship development in Shenzhen, China. Relevant suggestions are presented in the end.
\end{abstract}

\section{Introduction}

Chinese economic reform started from the bottom up. The government was not able to legitimize grass-roots entrepreneurial activities, as the political and legal framework was missing in the 1970s. To reveal the dynamic power for the initiative activities and its inner logic in entrepreneurship development in China, this research firstly introduces the theoretical framework about environmental determinants of entrepreneurship, with particular regard to Shane's argument on institutional environments and Douglass North's view on institutions. Secondly, the research focuses on Shenzhen model to examine how informal institutions were produced and how the informal institutions transformed into formal institutions to improve the institutional environment. Finally, a comprehensive theoretical framework is developed to illustrate the nexus of the three issues, such as informal institution (core values of culture and social capital), the development of entrepreneurship and the institutions, which work as a whole to shape the distinctive qualities of entrepreneurship in China. Relevant suggestions on how to improve the entrepreneurial environment are presented in the end.

\section{Analysis of the theoretical framework}

\subsection{A general theory of entrepreneurship---the environment context of entrepreneurship}

Table 1. the effect of institutional environment on the willingness of people to engage in productive entrepreneurial activity (Shane, 2003).

Table 1. The Effect of Institutional Environment on Opportunity Exploitation

\section{Economic environment}

--Income and capital gains increase the level of opportunity exploitation, while property taxes reduce it.

--Economic growth and social wealth increase the level of opportunity exploitation. --Low rates of inflation and stable economic conditions increase the level of opportunity exploitation. 
2. Political environment

--Freedom increases the level of opportunity exploitation.

--Strong rule of law and property rights increase the level of opportunity exploitation.

--Decentralization of power increase the level of opportunity exploitation.

\section{Socio-cultural environment \\ --Social desirability of entrepreneurship increases the level of opportunity exploitation. \\ --Presence of entrepreneurial role models increases the level of opportunity exploitation. \\ --Specific cultural beliefs increase the level of opportunity exploitation.}

Source: Scott Shane (2003) “A General Theory of Entrepreneurship---the environment context of entrepreneurship" p.147

\subsection{Definitions and perspectives on socio-cultural environment}

Under conditions of uncertainty and information asymmetry, the socio-cultural environment is an important dimension of the context in which entrepreneurial activity takes place. The social norms and beliefs that support reciprocity and moral commitments encourage entrepreneurial activity by facilitating resource acquisition. The socio-cultural infrastructure consists of the beliefs and attitudes of the members of society towards what are desirable and legitimate activities (Shane 2003, p.157).

\subsection{New institutional theory and institutional subversion and conversion}

As defined by North, institutions are a set of rules or, more formally, are the human devised constraints that shape human interaction. The distinction between an organization and an institution is an item to be argued. Consistent with North's view, organizations is taken as "players" in the economy whereas institutions as "a rule of game" (North 1990, p.5). Formal institutions are codified in law; they carry the weight of legal sanctions. Informal institutions may be understood as the collection of social norms, conventions, and moral values that constrain individuals and organizations in pursuit of their goals. The idea of social capital in the Chinese context captures the indigenous social phenomenon called guanxi (connections). It is created by trust, mutual obligation, expectations, and norms among network members (Gulatin 1995, p.85-112). The trust system and networks act as motivational factors to force the intermediate process change, and this leads to the innovation of the institutional environment, either in a subversion or a conversion way.

Institutional subversion and conversion are different expressions of processes that give rise to adaptive informal institutions. Institutional subversion occurs when people ignore formal institutions. Institutional conversion occurs when actors appropriate formal institutions to serve their own ends (Thelen, 2004).

\section{The development of immigrant entrepreneurship in Shenzhen}

The development of entrepreneurship in Shenzhen can be traced back to the establishment of SEZ in 1978. The power and legitimacy of SEZ granted by the central government approved Shenzhen's local government to provide a flexible institutional environment for the development of entrepreneurship in Shenzhen. Shenzhen's economic strategy in the 1980s connected the mainland with foreign countries and provided the entrepreneurs with many entrepreneurial opportunities. The development of entrepreneurship forced the government to make innovations against old regulations and to implement permissive laws. Many private high-tech enterprises such as Huawei Group took flexible measures to cooperate with their partners and to react quickly to the market. During the 
1990s, many organizations such as the entrepreneurial technology parks for high-tech R\&D, service centers for foreign-invested enterprises, etc. were established in response to the incentives of the institutional system. However, there is a weak awareness of property rights and freedom in the contemporary Chinese political environment. High inflation and unstable economic conditions make it very difficult for the entrepreneurs to enact forward-looking decisions. The development of entrepreneurship in Shenzhen needs more support from a free political institutional environment. The socio-cultural environment in Shenzhen was desirable and legitimate for the development of entrepreneurship. Decentralization and formalization enhance the process of innovation in the institution environment. The development of entrepreneurship forces the innovation of government management. Obviously, the development of entrepreneurship in Shenzhen is a process which blends institutional entrepreneurship, social entrepreneurship and business entrepreneurship and all these accelerate the institutional change to boost economic growth. In the institutional transformation, a diversified and diversifying "culture of innovative entrepreneurship" (Faltin 2001) can promote sustainability because it is based on the questioning of common business "solutions". It also indicates that the entrepreneurial transformation is in need of formal institutions. The political and institutional reform has begun in Shenzhen. This is the reason why Shenzhen was again selected as a special zone for political reform in China upon entering the $21^{\text {st }}$ century.

\section{Summary}

This study attempts to discover the relationship between institutions and entrepreneurship and to discuss how to improve the entrepreneurship environment in contemporary China. The business models of Shenzhen have evolved in different institutional environments and show the effects of institutions on entrepreneurial activity and the influence of entrepreneurial development on the transformation of institutions. Figure 1 shows the relationship between the formal and informal institutional framework, the social capital/culture and the development of entrepreneurship.

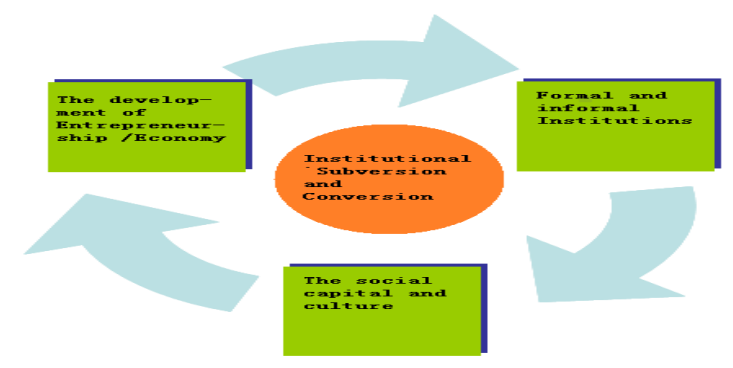

Fig.1. A Framework on the Interaction of Social Capital/Culture, Institutions and Entrepreneurship

\section{References}

[1]. Faltin, G., Creating a Culture of Innovative Entrepreneurship: Journal of International Business and Economy. Vol.2, No.1 2001.

[2]. Gulatin, R., Does Familiarity Breed Trust? The Implications of Repeated Ties for Contractual Choice in Alliances: Academy of Management Review, Vol.38 (1), pp. 85-112, 1995.

[3]. North, Douglass. C., , Institutions, Institutional Change and Economic Performance, Cambridge, UK: Cambridge University Press,p.3,1990.

[4]. Shane, S., A General Theory of the Entrepreneurship - the Individual -opportunity Nexus Edward Elgar Publishing Limited ,p.147,p.157. 2003.

[5]. Thelen, K., Timing and Temporality in the Analysis of Institutional Evolution and Change, 
Studies in American Political Development 14, no.1:101-108 , 2004 in Kellee S. Tsai, Capitalism without Democracy- the Private Sector in Contemporary China, Cornell University Press, pp. 208-209, 2007. 